\title{
Long-term Observation of Atmospheric Pollution in an Industrial Region in North-East Bulgaria during 2000-2015: Possibilities to Improve Air Quality
}

\author{
Rozalina Zlateva Chuturkova \\ (Department of Ecology and Environmental Protection \\ Technical University, Varna, Bulgaria)
}

\begin{abstract}
A long-term research was made (2000-2015) of air pollution in the industrial region of Devnya, located in North-east Bulgaria. It has powerful industrial enterprises of great significance for the national economy: production of soda ash, nitrogen and phosphorus fertilisers, clinker and cement, as well as a coalfired thermal power plant. Basic pollutants were studied: $\mathrm{SO}_{2}, \mathrm{NO}_{2}, \mathrm{CO}, \mathrm{O}_{3}, \mathrm{PM}_{10}, \mathrm{NH}_{3}$ and $\mathrm{C}_{6} \mathrm{H}_{6}$. The results indicate a significant decrease in the concentrations of all air pollutants after the introduction of the IPPC permits for the industrial and combustion plants (2005-2006) for the implementation of best available techniques, efficient purification facilities of waste gases, and strict control of harmful substances. The concentrations of pollutants at the end of period are much lower than in comparison with the start of the study, and the differences are of high statistical significance $(0.001 \leq P \leq 0.05)$. Implementation of the measures in IPPC permits, as well as measures aimed at light-and heavy-duty vehicles, fugitive emissions, an information campaign among the population regarding the quality of the fuels used and their impact on air pollution, as well as energy efficiency of buildings and its impact on fuel consumption, etc., are contributing to improving air quality.
\end{abstract}

Keywords: air pollution, $\mathrm{SO}_{2}, \mathrm{NO}_{2}, \mathrm{CO}, \mathrm{O}_{3}, \mathrm{PM}_{10}, \mathrm{NH}_{3}, \mathrm{C}_{6} \mathrm{H}_{6}$, IPPC permits, measures to improve air quality

\section{Introduction}

The requirements of the Law on Clean Air in Bulgaria are aimed at all anthropogenic sources of pollution: the designed, built and operational facilities with industrial, and non-industrial function; transport vehicles and other individual sources of pollution; construction and other open air facilities and sites; construction, destruction, mining, communal, transport, agricultural and other activities [1]. For industrial and combustion plants, are essential requirements of Council Directive 96/61/EC concerning integrated pollution prevention and control of pollution in order to prevent or reduce the emissions of harmful and hazardous substances into the air, water and soil, including measures for the prevention of their formation and legal management of waste [2]. Council Directive 96/61/EC based on several principles - integrated approach, best available techniques, flexibility and public participation. At the national level, the Directive was transposed into the Ordinance on the terms and order for issuing permits for Integrated Pollution Prevention and Control (IPPC permits) [3]. The building and operation of new and existing facilities and installations for certain categories of industrial operations is allowed only after the issuing of IPPC permits. The operator of the installation submits to the relevant authority (Ministry of the Environment and Water Resources) an application to be issued a permit, including: description of the installation; the used raw materials; the used and/or generated electricity; type and quantity of the emissions expected, as well as their possible significant impact on the environment, etc.

The IPPC permit as per Article 117 of the Law on Environment Protection [4] is issued by the relevant authority and contains emission norms and technical measures; compulsory measures for protection of air, water and soil; requirements for monitoring; conditions for limiting transboundary pollution; additional measures for achieving the applicable norms for environmental quality. It includes the necessary conditions to ensure compliance of the installation with the requirements of the law. Council Directive 96/61/EC was amended significantly several times and was then superseded by Council Directive 2008/1/EC without prejudice to the obligations of the member states concerning the terms for transposition of the Directive in their national legislation [5].

Some authors review the interrelation between industrial activities, air and environment pollution as one whole. They study the use of electricity, the productivity of enterprises, the amount of the means for technological development and scientific research. In their research, they establish that the regulations concerning industrial enterprises successfully reduce the intensity of air pollution [6]. Other authors study air pollution in the industrial areas by tracing the variations of the different pollutants. When analysing ambient air in industrial areas for $\mathrm{SO}_{2}, \mathrm{NO}_{\mathrm{x}}, \mathrm{CO}, \mathrm{O}_{3}$ and $\mathrm{PM}_{10}$, Doğrupamak S. C., B. Özbay, 2011 and Yoo J. M. et al. 2015 determine that the highest amounts of $\mathrm{SO}_{2}$ and $\mathrm{PM}_{10}$ were in the daily, weekly and annual concentrations 
[7, 8]. Also high are the concentrations of the particulate matter, $\mathrm{SO}_{2}, \mathrm{NO}_{x}, \mathrm{CO}$ and $\mathrm{PM}_{10}$, established in the analyses by Harinath S., V. Murthy, 2010 and Setimo G., 2014 in an industrial area, exceeding the admissible norms $[9,10]$. The authors specify that the organising of air quality monitoring in industrial areas is of exceptional importance for the prudent planning of the future development of industry. In areas with presence of metallurgical plants, chemical industries, enterprises of building materials and coal fired power plants, observed increased concentrations of $\mathrm{SO}_{2}$ and $\mathrm{NO}_{2}$ - from 1.25 to 2.25 times above admissible norm for $\mathrm{NO}_{2}$ for the period 2010-2015, as well as high $\mathrm{PM}_{10}$ concentrations [11-13]. Civan et al., 2015 study air pollution in an industrial area with various anthropogenic sources (metallurgical enterprises, petrochemical industrial complexes, petroleum refineries, gas power plant) with volatile organic compounds ( $\mathrm{VOCs}$ ), $\mathrm{NO}_{2}, \mathrm{SO}_{2}, \mathrm{O}_{3}$, and they established the existence of high levels of VOCs, $\mathrm{NO}_{2}$ and $\mathrm{SO}_{2}$ [14]. The concentrations of most VOCs are higher during the winter because of the lower mixing height.

Many authors trace the seasonal variations in industrial pollution. Sarasamma J. O., B. K. Narayanan, 2014; Mohamed R. M. S. R. et al. 2015 study air pollution in an industrial area with total suspended particulate matter (TSP), $\mathrm{PM}_{10}, \mathrm{SO}_{2}, \mathrm{NO}_{2}$ and $\mathrm{Cl}_{2}$ with a focus on seasonal variations (summer-winter) and a study of the meteorological parameters $[15,16]$. They established that the concentrations of $\mathrm{SO}_{2}$ and $\mathrm{NO}_{2}$ are within the limits of the national standards for air quality and the concentrations of TSP and $\mathrm{PM}_{10}$ are higher during the winter than in the summer, because of home heating. Karar K. et al., 2006 also studied the seasonal variations of TSP and $\mathrm{PM}_{10}$ and found much higher values during the winter than during the other seasons [17]. The average daily concentrations of $\mathrm{PM}_{10}$ vary from 62.4 to $401.2 \mu \mathrm{g} / \mathrm{m}^{3}$, and for TSP - from 125.0 to $732.1 \mu \mathrm{g} / \mathrm{m}^{3}$. Exploring industrial pollution with $\mathrm{SO}_{2}, \mathrm{NO}_{2}$ and $\mathrm{O}_{3}$, Pekey B., Ü. Özaslan, 2013 found that concentrations of $\mathrm{SO}_{2}$ and $\mathrm{NO}_{2}$ are from 2 to 4 times higher in the industrial area compared to rural areas, and the values are higher in winter compared to summer months: for $\mathrm{SO}_{2}$ - average $8 \mu \mathrm{g} / \mathrm{m}^{3}$, max. $40 \mu \mathrm{g} / \mathrm{m}^{3}$ (summer) and an average of $25 \mu \mathrm{g} / \mathrm{m}^{3}$, max. $61 \mu \mathrm{g} / \mathrm{m}^{3}$ (winter); for $\mathrm{NO}_{2}$ - an average of $14 \mu \mathrm{g} / \mathrm{m}^{3}$, max. $82 \mu \mathrm{g} / \mathrm{m}^{3}$ (summer) and an average of $50 \mu \mathrm{g} / \mathrm{m}^{3}$, max. $100 \mu \mathrm{g} / \mathrm{m}^{3}$ (winter) [18]. The maximum concentrations of $\mathrm{O}_{3}$ are $86 \mu \mathrm{g} / \mathrm{m}^{3}$ during the summer and $61 \mu \mathrm{g} / \mathrm{m}^{3}$ during the winter. In a region with power stations, there are higher concentrations of $\mathrm{SO}_{2}$, $\mathrm{NO}_{2}$ and VOCs in the air during the winter than during the summer. Significantly higher values of $\mathrm{SO}_{2}$ observed in residential areas, where the population used coal for heating. The hazard of developing cancer relates to the inhaling of benzene - its concentrations are higher during the winter months [19]. It has been established that the inhabitants of industrial areas have higher numbers of daily hospitalisations for respiratory and heart diseases, skin and eye disease, especially during the winter period - the concentrations of $\mathrm{PM}_{10}, \mathrm{PM}_{2.5}, \mathrm{SO}_{2}$ and $\mathrm{NO}_{2}$ are higher during the winter as compared to the summer [20,21]. When studying lung cancer rate in an industrial area in northern Spain, it was established that air pollution in this industrial area is a relatively low risk factor for lung cancer [22]. Made a survey on public awareness of the impact of industrial pollution on the respiratory system, $91.1 \%$ of respondents are aware of the causes of pollution in their area; $88.9 \%$ - of the effects of air pollution from industry on health and 90.0 percent indicated that respiratory problems are associated with industrial smoke [23]. Khaniabadi Y. O. et al. 2016 determined that the higher concentrations of $\mathrm{PM}_{10}, \mathrm{NO}_{2}$ and $\mathrm{O}_{3}$ in industrial areas raise the death rate from heart disease, which requires taking suitable measures for reduction of emissions of polluting substances and ozone precursors in the region - mainly from coal fired power plants and motor vehicles [24]. A study of air pollution with $\mathrm{NO}_{\mathrm{x}}, \mathrm{SO}_{2}$ and VOCs in an industrial area with petrochemical production determined that the average concentrations of VOCs exceed the standards for air quality while the average concentrations of $\mathrm{NO}_{\mathrm{x}}$ and $\mathrm{SO}_{2}$ are below the admissible norms. An action plan was proposed and measures for reducing the pollution in the area [25]. Air pollution from industrial sources also has a many negative social-economic consequences by contributing to the global greenhouse effect and the ozone layer depletion [26].

The aim of this research is to study air pollution in the industrial area for an extended period of time prior to the issuance of IPPC permits for industrial and combustion plants and enough time after their entry into force to assess the impact of measures to improve air quality, as well as measures aimed at other sources of pollution.

\section{Material And Method}

The research was carried out in the industrial region of Devnya, located in the northeastern part of Bulgaria. In it built powerful industrial enterprises of importance to the national economy of the country:

- "Solvay Sodi" AD for the production of soda ash by ammonia Solvay process;

- "Agropolychim" AD for the production of nitrogen and phosphate fertilizers;

- "Devnya Cement" AD, which uses wet and dry method for the production of clinker and cement;

-"Polymers" AD for the production of chlorine and chlorine products, and "Deven" AD for cogeneration of electricity and heat consumed by the factories of the industrial area.

The geographical location of Devnya benefits the development of the transport system servicing not only the national but the international infrastructure destinations as well. Water transport is of specific 
importance for the region, represented by Varna Zapad /Varna-West/ Port AD, which is one of the most developed ports in the world. It mainly supports the transport of raw materials and produce from the enterprises located on the territory of Devnya industrial region. Road transport includes national and local significance highways and roads, the most important national road being Hemus Motorway.

Traced is ambient air pollution in the industrial region in a station of the National system for monitoring ambient air quality to the Executive Environment Agency in Bulgaria. The automatic measuring station (AMS) Izvorite is located in the central part of Devnya and is a combined industrially orientated urban background station with a range of $10-100 \mathrm{~m} / 100 \mathrm{~m}-2 \mathrm{~km}$. The station has been functioning as an automatic measurement station as of 1990 with Eoi code BG0013A - Dv1, coordinates $+043.13 .12 .00 /+027.33 .40 .00$ and 24-hour operation. The data from the automatic station do in real time in a regional dispatching centre and through him in the Central dispatching office at Executive Environment Agency, Sofia, where it formed a national database on ambient air quality. At Izvorite the following pollutants are measured: sulphur dioxide, $\mathrm{SO}_{2}$, nitrogen dioxide, $\mathrm{NO}_{2}$, carbon oxide, $\mathrm{CO}$, ozone, $\mathrm{O}_{3}$, particulate matter with a diameter of $10 \mu \mathrm{m}\left(\mathrm{PM}_{10}\right)$, ammonia, $\mathrm{NH}_{3}$ and benzene, $\mathrm{C}_{6} \mathrm{H}_{6}$.

The survey covers a relatively long period of time 2000-2015, in order to evaliate the following:

- The condition of ambient air in the preparatory stage of Bulgaria becoming a member state of the EC;

- The harmonization of the Bulgarian with the European legislation and the influence exerted by the quality of air after Bulgaria became a member state (2007);

- The transposition of the Directives on issuing permits for industrial and combustion plants for complex prevention and control of pollution;

- An evaluation of the effect from the measures set in these environmental documents, as well as the keeping of the norms on admissible emissions of separate harmful substances from the point sources in the industrial area.

In order to trace air pollution at Izvorite AMS for the period 2000-2015, data was used from the National System for Monitoring and the annual reports on the condition of the environment of the Regional Inspectorate of the Environment and Water Resources in the city of Varna [27] covering the monthly, seasonal and annual variations of atmospheric pollutants. The results from the monitoring of the different pollutants in ambient air are processed statistically with the variation analysis method and the differences have been evaluated employing Student-Fisher's t-distribution.

\section{Results And Discussion}

The results from the monitoring of ambient air in Devnya industrial region indicate that the concentrations of $\mathrm{PM}_{10}$ at the beginning of the research are significantly above the admissible norm almost during the whole year. In 2000, the monthly average concentrations of particulate matter vary from 63.26 to $230.73 \mu \mathrm{g} / \mathrm{m}^{3}$, and exceed the annual average human health safety norm (AAN $-45 \mu \mathrm{g} / \mathrm{m}^{3}$ ) between 1.41 and 5.13 times (fig.1). High concentrations of $\mathrm{PM}_{10}$ observed during the cold and the warm months of the year without any significant differences. The trend over the following years is analogous (2001-2003) - year-round excess pollution mainly from the industrial sources. In 2004, a sharp fall in the concentrations of $\mathrm{PM}_{10}$ in ambient air observed, with variations during the whole year from 10.11 to $30.08 \mu \mathrm{g} / \mathrm{m}^{3}$ and significantly above the admissible standard (AAN- $42 \mu \mathrm{g} / \mathrm{m}^{3}$ ). Analogous is the pollution over the following two years (2005-2006). In 2007, a different trend appeared in particulate matter air pollution. Higher concentrations of $\mathrm{PM}_{10}$ observed during the cold period (CP) - up to $49.54 \mu \mathrm{g} / \mathrm{m}^{3}$ and lower during the warm period (WP) of the year - up to $34.19 \mu \mathrm{g} / \mathrm{m}^{3}$, exceeding the admissible norm for human health 1.24 times. Similar is the trend in 2008 - up to $50.49 \mu \mathrm{g} / \mathrm{m}^{3}$ (CP) and up to $40.18 \mu \mathrm{g} / \mathrm{m}^{3}$ (WP) (fig.1). In 2009, the seasonal dependency retained, but the concentrations of $\mathrm{PM}_{10}$ during the whole year are quite low - up to $32.25 \mu \mathrm{g} / \mathrm{m}^{3}$. The dependencies over the following years (2010-2015) are analogous - pronounced seasonality with higher concentrations of $\mathrm{PM}_{10}$ during the cold months and lower during the warm months of the year, not exceeding the average daily human health safety norm $\left(\mathrm{AAN}-40 \mu \mathrm{g} / \mathrm{m}^{3}\right)$ [28].

The results from the study indicate that at the beginning of the period dominated by ambient air pollution with $\mathrm{PM}_{10}$ from the industrial sources, concentrated in the region of Devnya, because of which a yearround above norm pollution is observed. In relation with Bulgaria becoming an EC member and the harmonization of European and Bulgarian legislations on environment protection, all industrial and combustion plants on the territory of Devnya received IPPC Permits. They include emission limit values of hazardous substances from industrial processes, the best available techniques, introduction of new and efficient waste gases purification facilities, organizing their own monitoring of the emitted hazardous substances, etc.:

- IPPC permits No.68/2005 of Agropolihim AD; No.74/2005 of Solvay Sodi AD; No.93/2006 of Deven $A D$ Coal Fired Power Plant; No.63-H1/2007 of Devnya Cement AD (Updating Nos.63-H1-UO-A1/2013 and 63H1-ИО-A2/2014) and No.72/2006 of Polimeri AD (bankrupt as of 2010). 
Observing the requirements in the IPPC permits for the industrial enterprise has led to a fall of particulate matter emissions from the emitting facilities and to improvement of ambient air quality (AAQ) in the region. Therefore, the impact of industrial sources on ambient air pollution was reduced, and gradually the impact from home heating has risen, rendering clear-cut seasonal dependency - higher $\mathrm{PM}_{10}$ concentrations during the cold period and lower during the warm period of the year. The seasonal differences relate to particulate matter emissions as a result of home heating in the region when burning coal and firewood during the cold months of the year. The high values are the result from a combination of unfavourable meteorological conditions during the cold period (low wind speed, fog, temperature inversions) impeding diffusion and atmospheric dispersion of particulate matter.

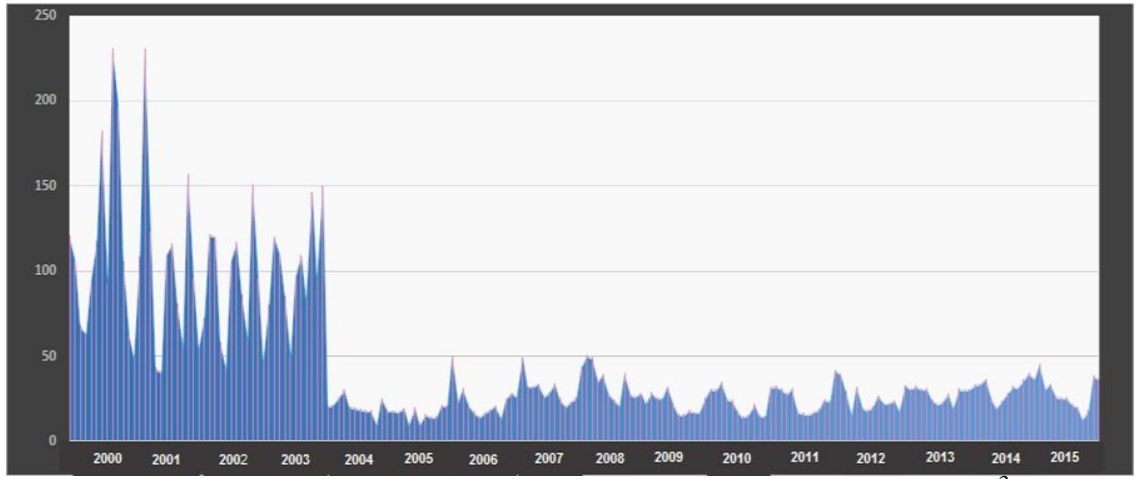

Fig.1. Monthly average $\mathrm{PM}_{10}$ concentrations in ambient air $\left(\mu \mathrm{g} / \mathrm{m}^{3}\right)$

The results from sulphur dioxide monitoring indicate that the concentrations of $\mathrm{SO}_{2}$ in the air of the industrial region during the whole sixteen-year period are low and significantly below the human health safety norm. At the beginning of the research (2000-2005) the $\mathrm{SO}_{2}$ concentrations varied from 10.02 to $17.82 \mu \mathrm{g} / \mathrm{m}^{3}$ (CP) and from 1.05 to $11.84 \mu \mathrm{g} / \mathrm{m}^{3}$ (WP) (fig.2), not exceeding the average daily human safety norm (ADN $125-150 \mu \mathrm{g} / \mathrm{m}^{3}$ for the period). Over the following years (2006-2010), the trend persisted, even though at slightly higher values - up to $22.70 \mu \mathrm{g} / \mathrm{m}^{3}(\mathrm{CP})$ and up to $13.59 \mu \mathrm{g} / \mathrm{m}^{3}$ (WP). After 2010 , the $\mathrm{SO}_{2}$ concentrations in ambient air decreased significantly during the whole year, and in 2015 the sulphur dioxide levels during the cold months reached up to $5.97 \mu \mathrm{g} / \mathrm{m}^{3}$, and during the warm ones - up to $4.09 \mu \mathrm{g} / \mathrm{m}^{3}$ (ADN-125 $\mu \mathrm{g} / \mathrm{m}^{3}$ ) [28].

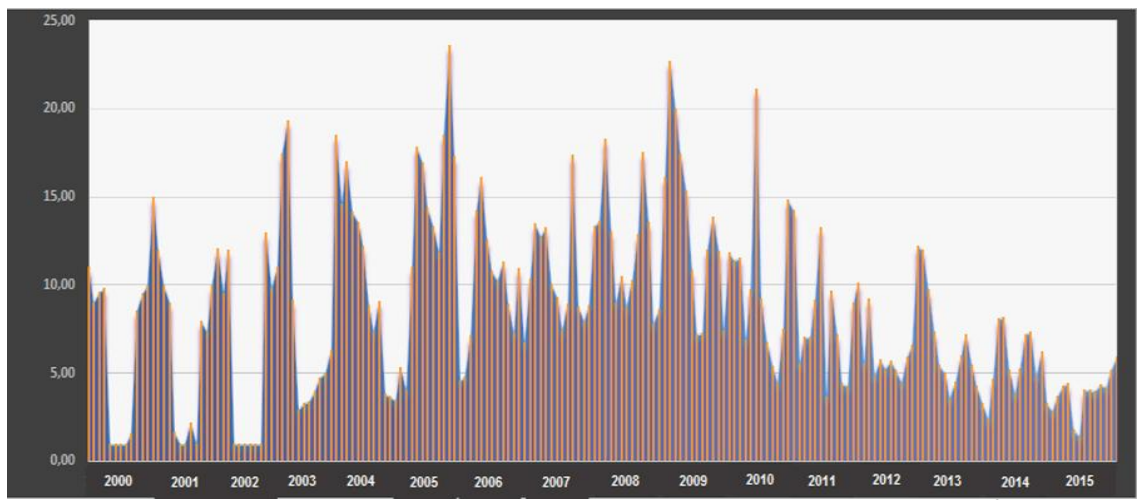

Fig.2. Monthly average $\mathrm{SO}_{2}$ concentrations in ambient air $\left(\mu \mathrm{g} / \mathrm{m}^{3}\right)$

Sulphur dioxide is a typical pollutant of ambient air during the cold period of the year. Air pollution comes mainly from burning fuels with high content of sulphur. As it has become clear, during the monitoring period the $\mathrm{SO}_{2}$ concentrations were significantly below the norm, but after the introduction of the IPPC permits for industrial and combustion plants in Devnya (2005-2007), the concentrations of $\mathrm{SO}_{2}$ fell even more and over the past years have been very low. From the operators' annual reports, we can see that the norms admissible emissions of $\mathrm{SO}_{2}$ as per the IPPC permits are not exceeded, which contributes for the improvement of AAQ in the region [29-32]. The main pollution comes from heating in residential and public sector it as Bulgarian lignite coal, which is widely used by the population for heating and cooking, contain from 2.5 to $4 \% \mathrm{~S}$.

The results from the monitoring of $\mathrm{NO}_{2}$ indicate that the concentrations of nitrogen dioxide at the beginning of the research (2000-2003) were relatively low, below the annual average human health safety norm (AAN 54-60 $\mu \mathrm{g} / \mathrm{m}^{3}$ for the period), without having any expressed seasonal dependency - with variations from 3.2 to $17.0 \mu \mathrm{g} / \mathrm{m}^{3}$ (fig.3). In 2004, the concentrations of $\mathrm{NO}_{2}$ are a little higher during the whole year - from 
15.31 to $29.99 \mu \mathrm{g} / \mathrm{m}^{3}$, without expressed seasonal dependency, not exceeding the norm (AAN $-52 \mu \mathrm{g} / \mathrm{m}^{3}$ ). In 2006, the values of $\mathrm{NO}_{2}$ are the highest, almost during the whole year and reach up to $78.41 \mu \mathrm{g} / \mathrm{m}^{3}$, and exceed the norm $\left(\mathrm{C} \Gamma \mathrm{H}-48 \mu \mathrm{g} / \mathrm{m}^{3}\right) 1.63$ times. Between 2007 and 2009, the $\mathrm{NO}_{2}$ concentrations gradually fell, with small variations during the different months, without exceeding the norm (fig.3). After 2010, the levels of $\mathrm{NO}_{2}$ in ambient air were even lower, but gradually a seasonal dependency emerged with values being a little higher during the cold months (up to $19.16 \mu \mathrm{g} / \mathrm{m}^{3}-2013$; up to $20.03 \mu \mathrm{g} / \mathrm{m}^{3}-2015$ ) and lower during the warm months -5.65 and $5.37 \mu \mathrm{g} / \mathrm{m}^{3}$ respectively. The annual average human health safety norm of $40 \mu \mathrm{g} / \mathrm{m}^{3}$ is not exceeded [28]. From the results, we can see that after the introduction of IPPC permits for the installations in Devnya industrial region, AAQ has improved and the emerging seasonal dependency after 2010 indicates mainly the influence on air pollution with $\mathrm{NO}_{2}$ from home and public building heating in the region.

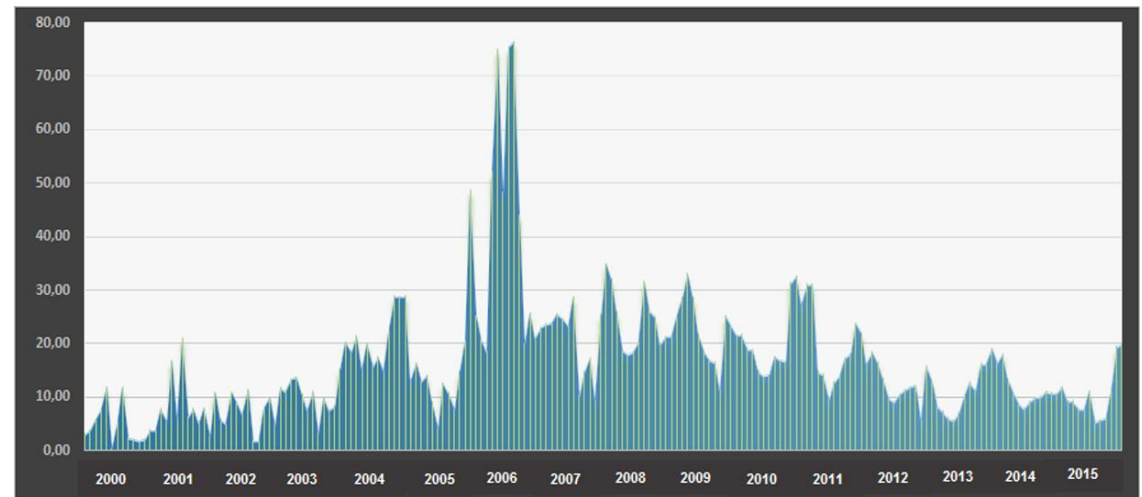

Fig.3. Monthly average $\mathrm{NO}_{2}$ concentrations in ambient air $\left(\mu \mathrm{g} / \mathrm{m}^{3}\right)$

Carbon dioxide data indicate that the $\mathrm{CO}$ concentrations at the beginning of the research reach up to $3.23 \mathrm{mg} / \mathrm{m}^{3}$ (2001), $3.15 \mathrm{mg} / \mathrm{m}^{3}$ (2002), $2.31 \mathrm{mg} / \mathrm{m}^{3}$ (2003) and up to $2.34 \mathrm{mg} / \mathrm{m}^{3}$ (2004), not exceeding the human health safety norm $-10 \mathrm{mg} / \mathrm{m}^{3}$ (fig.4) [28,33]. After 2005, seasonal dependency has emerged gradually in air pollution with carbon oxide - higher concentrations during the cold months and lower during the warm months of the year. In 2006, the levels of CO vary from 1.87 to $6.62 \mathrm{mg} / \mathrm{m}^{3}(\mathrm{CP})$ and from 0.38 to $0.74 \mathrm{mg} / \mathrm{m}^{3}$ (WP). The trend in 2007 is analogous - from 1.10 to $3.82 \mathrm{mg} / \mathrm{m}^{3}(\mathrm{CP})$ and from 0.34 to $0.73 \mathrm{mg} / \mathrm{m}^{3}$ (WP). In 2008, the monthly average CO concentrations are already quite lower - from 0.96 to $1.86 \mathrm{mg} / \mathrm{m}^{3}$ (CP) and from 0.30 to $0.70 \mathrm{mg} / \mathrm{m}^{3}$ (WP). In 2010, the values of CO in ambient air are even lower, but still retaining seasonality in pollution - from 0.42 to $0.86 \mathrm{mg} / \mathrm{m}^{3}(\mathrm{CP})$ and from 0.22 to $0.46 \mathrm{mg} / \mathrm{m}^{3}$ (WP). This trend is retained all through the study, with 2014 and 2015 concentrations of CO reaching up to $0.54 \mathrm{mg} / \mathrm{m}^{3}(2014 \Gamma)$ and $0.50 \mathrm{mg} / \mathrm{m}^{3}$ (2015 г) during the cold period and to $0.33 \mathrm{mg} / \mathrm{m}^{3}$ (2014) and $0.37 \mathrm{mg} / \mathrm{m}^{3}$ (2015) during the warm period of the year.

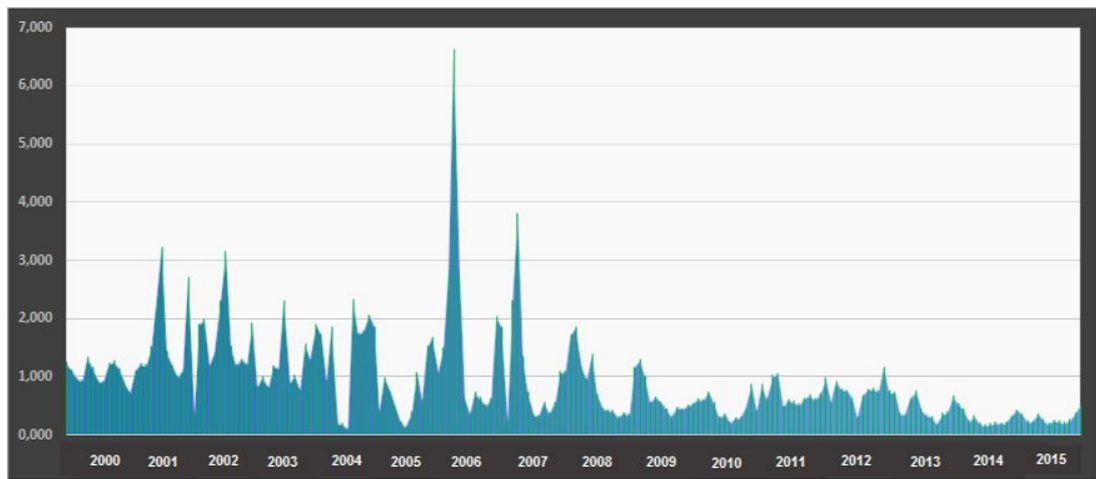

Fig.4. Monthly average CO concentrations in ambient air $\left(\mathrm{mg} / \mathrm{m}^{3}\right)$

When studying air pollution with $\mathrm{CO}$, we yet again see the relationship between the introduction of IPPC permits for industrial and combustion plants, the implementation of best available techniques, the control on the norms for admissible emissions and the improvement of air quality. The seasonal dependency in air pollution with CO mainly relates to burning fossil fuels for home heating. The low temperature in domestic stoves creates conditions for incomplete combustion of fuels and formation of high concentrations during the cold months of the year.

Ozone is a secondary pollutant forming as a result of photochemical reactions to volatile organic compounds, nitrogen oxides and $\mathrm{CO}$ under the influence of high temperature and ultraviolet sun radiation. As of 
the beginning of the research, seasonal dependencies in air pollution with ozone are observed - higher concentrations during the warm period and lower during the cold period of the year. The ozone concentrations reach up to $55.82 \mu \mathrm{g} / \mathrm{m}^{3}(2001)$ and $49.86 \mu \mathrm{g} / \mathrm{m}^{3}$ (2002) during the warm months and to $19.71 \mu \mathrm{g} / \mathrm{m}^{3}(2001)$ and $19.24 \mu \mathrm{g} / \mathrm{m}^{3}$ (2002) during the cold months of the year (fig.5). Over the following years, the trends are analogous but the concentrations are higher. In 2003, $\mathrm{O}_{3}$ concentrations vary from 54.37 to $84.21 \mu \mathrm{g} / \mathrm{m}^{3}$ (WP) and from 24.66 to $78.55 \mu \mathrm{g} / \mathrm{m}^{3}(\mathrm{CP})$. After 2005 , the $\mathrm{O}_{3}$ concentrations gradually fall and vary from 41.25 to $61.17 \mu \mathrm{g} / \mathrm{m}^{3}$ (2007) during the warm period and from 28.63 to $44.09 \mu \mathrm{g} / \mathrm{m}^{3}$ during the cold period. These dependencies are analogous over the following years, not exceeding the human health safety norm - maximum 8-hour average value $120 \mu \mathrm{g} / \mathrm{m}^{3}$ [28]. During the whole monitoring period, the threshold of $180 \mu \mathrm{g} / \mathrm{m}^{3}$ for informing the population and the threshold of $240 \mu \mathrm{g} / \mathrm{m}^{3}$ for warning the population have not been exceeded.

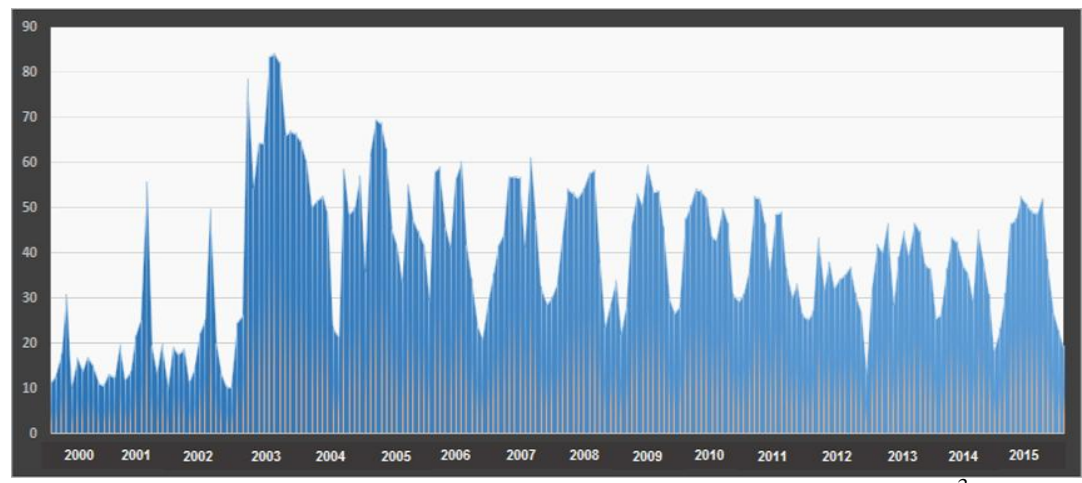

Fig.5. Monthly average $\mathrm{O}_{3}$ concentrations in ambient air $\left(\mu \mathrm{g} / \mathrm{m}^{3}\right)$

The monitoring of ammonia in ambient air covers a shorter period: 2006-2015. Before 2006, there were no regular measurements of this pollutant to form a database for statistical processing. From the results in fig. 6 we can see that in 2006 the monthly average $\mathrm{NH}_{3}$ concentrations are the highest and reach up to $44.19 \mu \mathrm{g} / \mathrm{m}^{3}$, not exceeding the average daily human safety norm (ADN-100 $\mu \mathrm{g} / \mathrm{m}^{3}$ ) [33]. During the following year, a sharp fall in air pollution was observed, with the concentrations of ammonia reaching up to $17.30 \mu \mathrm{g} / \mathrm{m}^{3}$. In 2008 , the levels of $\mathrm{NH}_{3}$ in the air are even lower - to $8.60 \mu \mathrm{g} / \mathrm{m}^{3}$. This trend is retained also over the following year, and in 2010 the $\mathrm{NH}_{3}$ concentrations are even lower - to $5.11 \mu \mathrm{g} / \mathrm{m}^{3}$, and the fall of the concentrations continuing over the following years - up to $0.91 \mu \mathrm{g} / \mathrm{m}^{3}(2011), 1.01 \mu \mathrm{g} / \mathrm{m}^{3}(2012)$, and to $1.25 \mu \mathrm{g} / \mathrm{m}^{3}(2014)$. In 2015 , the monthly average levels of ammonia reach up to $9.69 \mu \mathrm{g} / \mathrm{m}^{3}$ without exceeding the norm. Before 2006 .

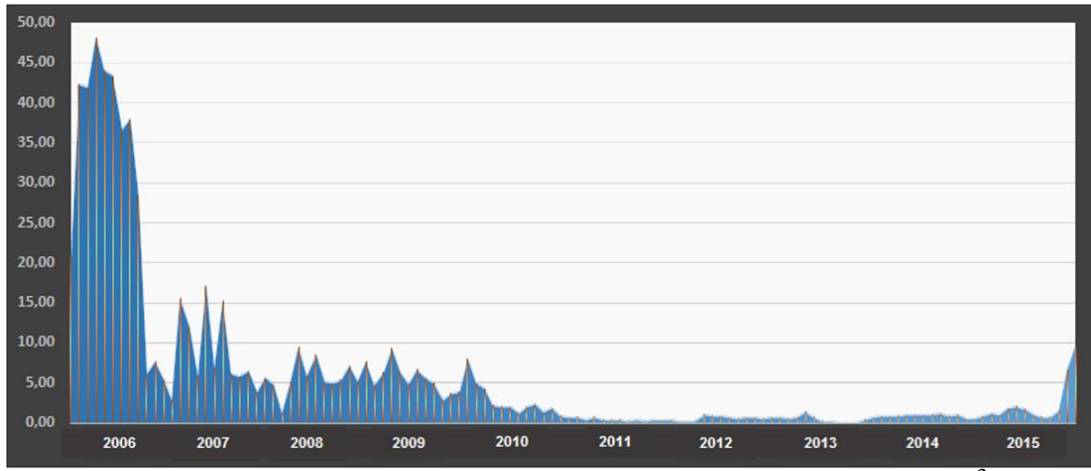

Fig.6. Monthly average $\mathrm{NH}_{3}$ concentrations in ambient air $\left(\mu \mathrm{g} / \mathrm{m}^{3}\right)$

The implementation of the requirements in the IPPC permits for the main sources of $\mathrm{NH}_{3}$ in the region - Agropolihim AD and Solvay Sodi $A D$ is one of the main reasons for the reduction of ammonia concentrations in ambient air $[29,30]$.

The monitoring of benzene also covers the 2006-2015 period. As of the beginning of the study, a clear seasonal dependency emerges - higher concentrations of $\mathrm{C}_{6} \mathrm{H}_{6}$ during the cold period as compared with the warm period of the year. In 2006, the benzene concentrations vary from 0.98 to $2.31 \mu \mathrm{g} / \mathrm{m}^{3}$ (CP) and from 0.22 to $0.82 \mu \mathrm{g} / \mathrm{m}^{3}$ (WP) (fig.7), not exceeding the annual average human health safety norm $-5 \mu \mathrm{g} / \mathrm{m}^{3}$ [28]. The trends over the following years are analogous. After 2010, lower $\mathrm{C}_{6} \mathrm{H}_{6}$ concentrations are observed - from 0.65 to $1.26 \mu \mathrm{g} / \mathrm{m}^{3}$ (2012) during the cold months and from 0.29 to $0.42 \mu \mathrm{g} / \mathrm{m}^{3}$ during the warm months of the year. The $\mathrm{C}_{6} \mathrm{H}_{6}$ levels until the end of the period are low too, preserving the seasonal dependency in air pollution. Seasonal dynamics shows that the combustion processes in the region during the heating season in the 
household and public sectors are main sources of benzene. After the implementation of measures in the IPPC permits to reduce emissions of benzene, dominates the domestic combustion and road transport as sources of pollution.

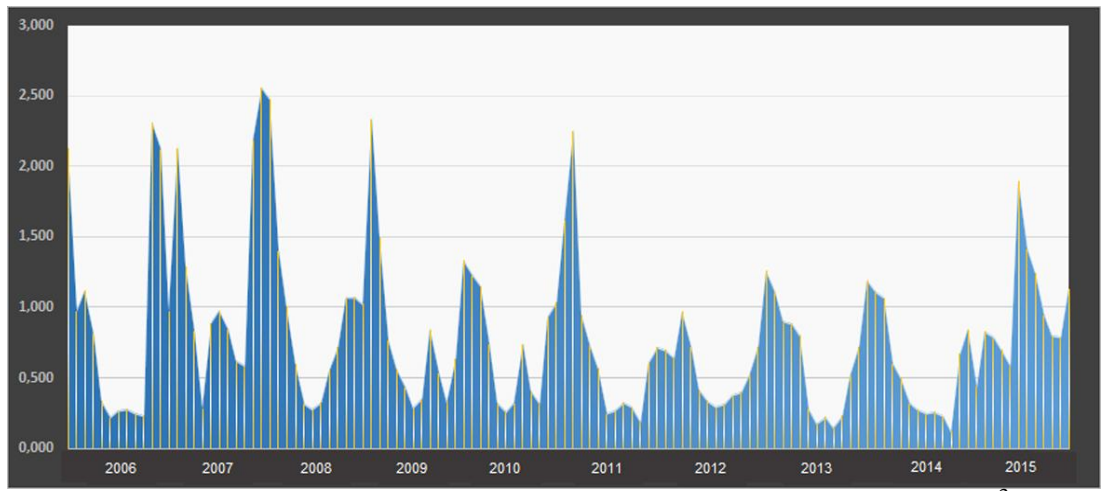

Fig.7. Monthly average $\mathrm{C}_{6} \mathrm{H}_{6}$ concentrations in ambient air $\left(\mu \mathrm{g} / \mathrm{m}^{3}\right)$

The results from the study of the annual average levels of air pollutants in Devnya industrial region indicate that at the beginning of the study (2000) the annual average $\mathrm{PM}_{10}$ concentration is $119.97 \mu \mathrm{g} / \mathrm{m}^{3}$ and gradually falls to $97.72 \mu \mathrm{g} / \mathrm{m}^{3}$ in 2003 , exceeding the annual average human health safety norm (AAN-45 $\mu \mathrm{g} / \mathrm{m}^{3}$ ) between 2.2 and 2.7 times. Over the next year, pollution with $\mathrm{PM}_{10}$ sharply falls to $19.72 \mu \mathrm{g} / \mathrm{m}^{3}$, and the difference in the concentrations has high statistical significance $(\mathrm{P}<0.001)$ (fig.8). During the following years, the $\mathrm{PM}_{10}$ concentrations are also quite low and vary from 19.29 to $27.72 \mu \mathrm{g} / \mathrm{m}^{3}$, and the differences, as compared with the start of the study, have high statistical significance $(\mathrm{P}<0.001)$. With small exceptions $(2007$, 2008 and 2014), the annual average $\mathrm{PM}_{10}$ concentrations exceeds the AAN 1.1 times.

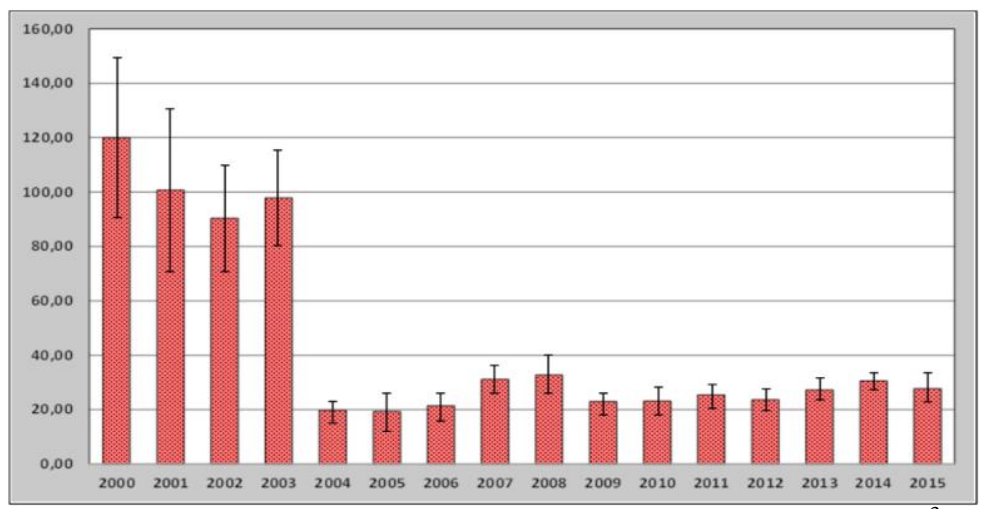

Fig.8. Annual average $\mathrm{PM}_{10}$ concentrations in ambient air $\left(\mu \mathrm{g} / \mathrm{m}^{3}\right)$

The results for sulphur dioxide indicate that the $\mathrm{SO}_{2}$ concentrations vary over the years within quite small limits, and do not exceed the $\mathrm{ADN}$ of $125 \mu \mathrm{g} / \mathrm{m}^{3}$. At the beginning of the study (2000), the annual average $\mathrm{SO}_{2}$ concentration is $6.09 \mu \mathrm{g} / \mathrm{m}^{3}$, rising to $13.45 \mu \mathrm{g} / \mathrm{m}^{3}$ in $2005(\mathrm{P}<0.01)$, and the pollution is retained around these values until 2010 (fig.9). After 2010, the $\mathrm{SO}_{2}$ concentrations gradually fall and in 2015 reach up to 3.97 $\mu \mathrm{g} / \mathrm{m}^{3}(\mathrm{P}<0.001)$.

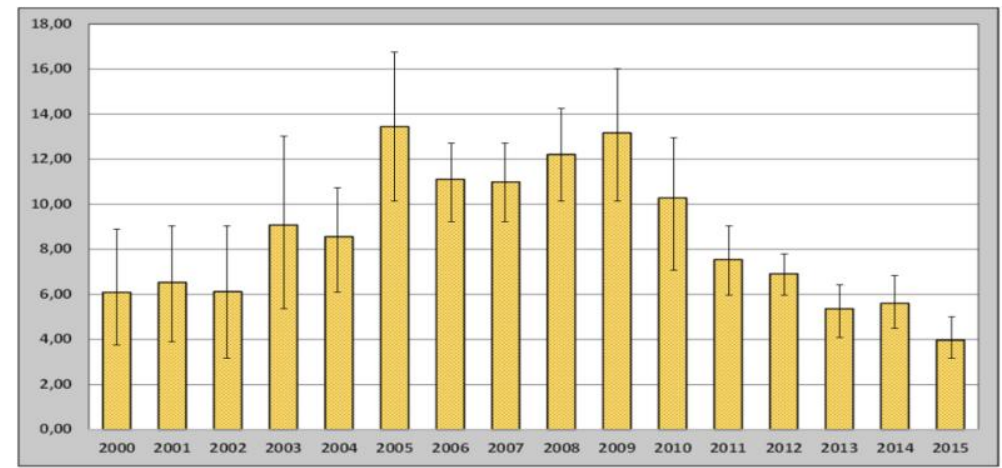

Fig.9. Annual average $\mathrm{SO}_{2}$ concentrations in ambient air $\left(\mu \mathrm{g} / \mathrm{m}^{3}\right)$ 
The results for nitrogen dioxide show that the annual average $\mathrm{NO}_{2}$ concentrations during the whole sixteen-year period of monitoring are under the admissible human health safety norm. At the beginning of the study (2000), the annual average $\mathrm{NO}_{2}$ concentration is $15.41 \mu \mathrm{g} / \mathrm{m}^{3}$, falling to $11.22 \mu \mathrm{g} / \mathrm{m}^{3}$ in $2003(\mathrm{P}<0.01)$ and rising to $44.48 \mu \mathrm{g} / \mathrm{m}^{3}$ in $2006\left(\mathrm{P}<0.001\right.$ ) (fig.10). After 2006, the annual average $\mathrm{NO}_{2}$ concentrations fall to $20.93 \mu \mathrm{g} / \mathrm{m}^{3}(\mathrm{P}<0.01)$ and stay within this range until 2011. After 2011, even greater reduction of the $\mathrm{NO}_{2}$ levels is observed and in 2015 they reach up to $10.50 \mu \mathrm{g} / \mathrm{m}^{3}(\mathrm{P}<0.025)$.

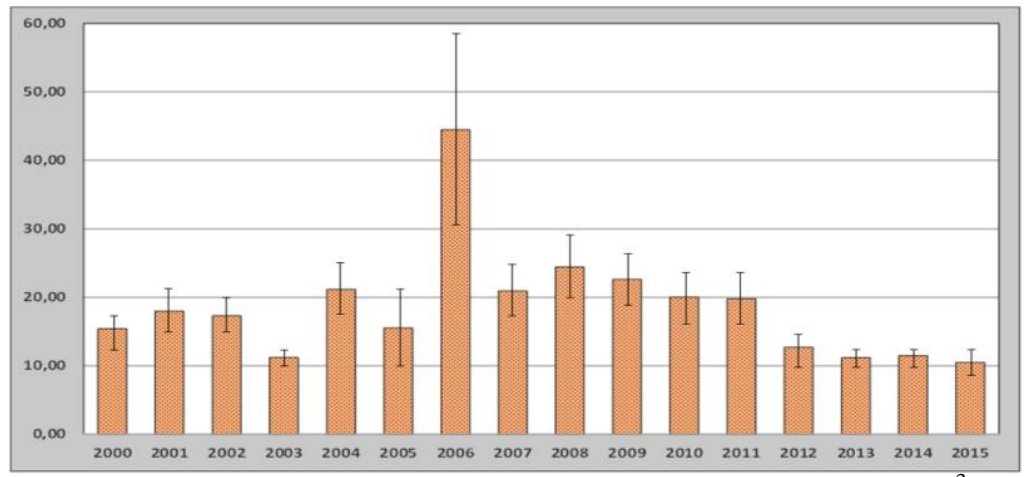

Fig.10. Annual average $\mathrm{NO}_{2}$ concentrations in ambient air $\left(\mu \mathrm{g} / \mathrm{m}^{3}\right)$

From the results for carbon oxide, we can see that the annual average $\mathrm{CO}$ concentrations during the period (2000-2007) vary from 0.87 to $1.66 \mathrm{mg} / \mathrm{m}^{3}$ (fig. 11 ). After 2007 , the CO levels gradually fall to 0.51 $\mathrm{mg} / \mathrm{m}^{3}$ (2010), $0.47 \mathrm{mg} / \mathrm{m}^{3}(2013)$ and to $0.30 \mathrm{mg} / \mathrm{m}^{3}(2015)$, and the differences are of high statistical significance $(0.001 \leq \mathrm{P} \leq 0.05)$.

The results for ozone in ambient air indicate that the annual average $\mathrm{O}_{3}$ concentrations at the beginning of the study (2000-2002) are relatively low and vary from 14.98 to $19.73 \mu \mathrm{g} / \mathrm{m}^{3}$ (fig. 12). After 2002 , the levels of $\mathrm{O}_{3}$ reach up to $63.56 \mu \mathrm{g} / \mathrm{m}^{3}$ (2003), and this rise has high statistical significance $(\mathrm{P}<0.001)$. During the following year, the ozone concentrations fall to $48.93 \mu \mathrm{g} / \mathrm{m}^{3}(\mathrm{P}<0.05)$ and this level of pollution is retained over the following year as well. After 2005, the annual average $\mathrm{O}_{3}$ concentrations fall even more and vary between 31.31 and $44.46 \mu \mathrm{g} / \mathrm{m}^{3}$, and the differences are of high statistical significance $(0.001 \leq \mathrm{P} \leq 0.05)$.

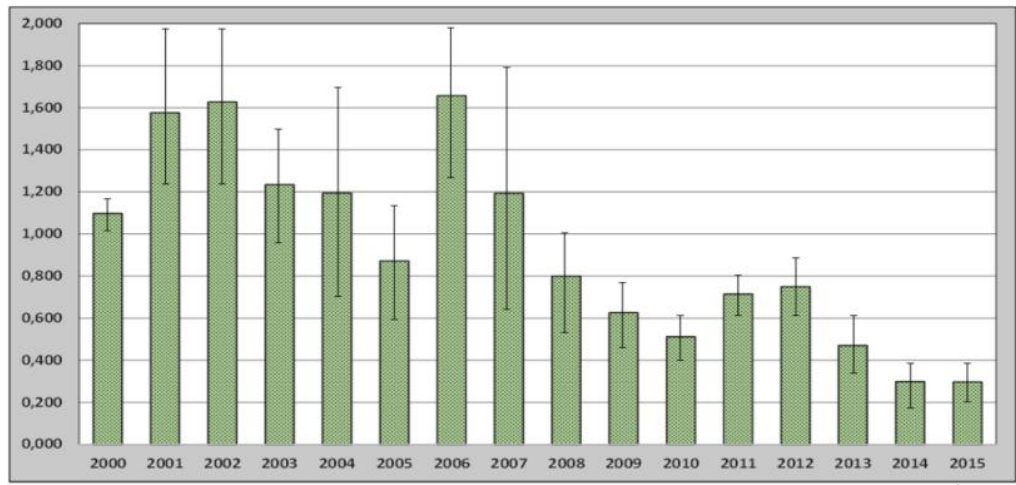

Fig.11. Annual average $\mathrm{CO}$ concentrations in ambient air $\left(\mathrm{mg} / \mathrm{m}^{3}\right)$

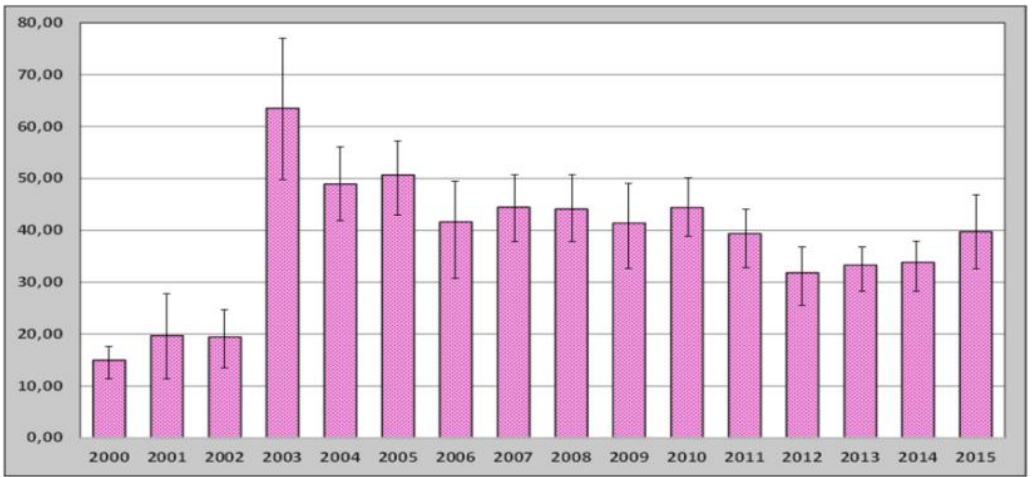

Fig.12. Annual average $\mathrm{O}_{3}$ concentrations in ambient air $\left(\mu \mathrm{g} / \mathrm{m}^{3}\right)$ 
From the data in fig.13, we can see that the highest annual average concentration of ammonia is in $2006-30.56 \mu \mathrm{g} / \mathrm{m}^{3}$, and during the following year it falls sharply to $8.73 \mu \mathrm{g} / \mathrm{m}^{3}(\mathrm{P}<0.001)$. Over the following years, the annual average $\mathrm{NH}_{3}$ concentrations fall even further - to $2.27 \mu \mathrm{g} / \mathrm{m}^{3}$ (2010) and to $0.54 \mu \mathrm{g} / \mathrm{m}^{3}$ (2011), and the differences again are of high statistical significance $(\mathrm{P}<0.001)$. In the period 2012-2014, the $\mathrm{NH}_{3}$ values are within the range of $0.62-1.02 \mu \mathrm{g} / \mathrm{m}^{3}$ and rise slowly to $2.53 \mu \mathrm{g} / \mathrm{m}^{3}$ in $2015(\mathrm{P}<0.05)$.

Pollution with benzene is relatively monotonous. In the period 2006-2008, the annual average concentrations vary from 0.91 to $1.19 \mu \mathrm{g} / \mathrm{m}^{3}$ (P>0.05). After 2009 , the $\mathrm{C}_{6} \mathrm{H}_{6}$ concentrations gradually fall and vary from 0.60 to $0.76 \mu \mathrm{g} / \mathrm{m}^{3}$ (fig.14). In 2014 , the annual average $\mathrm{C}_{6} \mathrm{H}_{6}$ concentration is the lowest -0.52 $\mu \mathrm{g} / \mathrm{m}^{3}$, and a statistically significant increase is observed in $2015-\mathrm{up}$ to $0.97 \mu \mathrm{g} / \mathrm{m}^{3}(\mathrm{P}<0.01)$.

The results from the long-term observation of ambient air indicate that after the introduction of the requirements in the IPPC permits in the industrial and combustion plants (2005-2006) for implementing best available techniques, efficient purifications facilities and strict control of the emitted hazardous substances, a significant fall of the concentrations of all studied pollutants in ambient air is observed. Other research we have conducted indicates a gradual fall in the reported emission of hazardous substances as per the European Pollutant Release and Transfer Register in the main industries in the territory of Devnya region - Agropolihim $A D$, Solvay Sodi $A D$ and Deven $A D$ Coal Fired Power Plant after the introduction of the IPPC permits [34-36]. After introducing suitable catalysts for reducing the greenhouse gas nitrous oxide $\mathrm{N}_{2} \mathrm{O}$ in the Nitric Acid Plant at Agropolihim AD (2005), a fall in $\mathrm{N}_{2} \mathrm{O}$ emissions is observed, which has contributed for the improvement of air quality in the region. Reduce not only average hourly and annual $\mathrm{N}_{2} \mathrm{O}$ concentrations, but is reduced and the range of the spatial distribution of $\mathrm{N}_{2} \mathrm{O}$ in the surface layer of the atmosphere $[37,38]$. In other industrial areas of Southwestern and Southeastern Bulgaria, where several coal fired power stations and a lead-zinc plant are located, there is a downward trend in air pollution with $\mathrm{SO}_{2}$ for the period 2007-2013, mainly due to the policy of issuing of IPPC permits for industrial and combustion plants and strict control over compliance with the requirements [39].

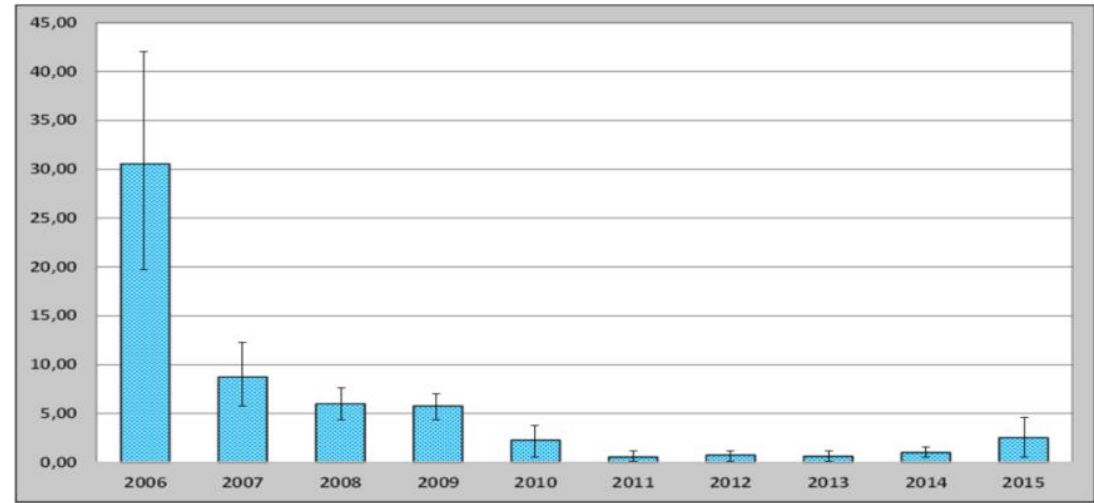

Fig.13. Annual average $\mathrm{NH}_{3}$ concentrations in ambient air $\left(\mu \mathrm{g} / \mathrm{m}^{3}\right)$

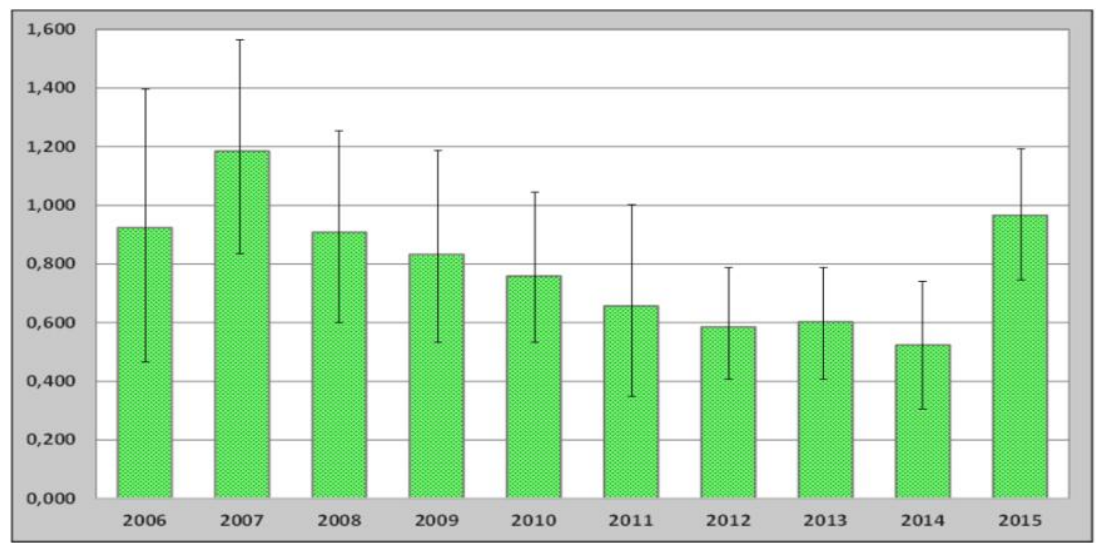

Fig.14. Annual average $\mathrm{C}_{6} \mathrm{H}_{6}$ concentrations in ambient air $\left(\mu \mathrm{g} / \mathrm{m}^{3}\right)$

Cafaro et al. 2015 also investigated the impact of IPPC permits for the industrial plants in a region with high concentration of industrial activities on air quality. In their research they established that the keeping of the requirements of Directive 2010/75/EO of industrial emissions (integrated pollution prevention and control), the frequency of the procedure for evaluation and the inclusion of measures for environment protection as a whole, 
contribute for the improvement of air quality in a given territory [40, 41]. The IPPC permits are important instruments for improving the condition of the environment and achieving the norms for pollutants in the air, thus giving the opportunity to evaluate the impact of industrial sources on air pollution in these areas.

Besides the measures directed at industrial sources of pollution through the IPPC permits for the territory of Devnya, measures have been implemented for limiting pollutants from moving sources through organisation and regulation of road traffic, including fees for avoiding traffic jams, differentiated parking charges, specified low emission zones, etc.[42]. Optimal travel routes are specified for light- and heavy-duty vehicles from the plants on the territory of Devnya industrial area to Varna-Zapad Port, control is increased over bulk trucks for total prevention of overloading and/or not using awnings. Measures are introduced for the use of low emission fuels in the stationary and moving sources. They include periodic adjustment of the combustion process of heating boilers in the utilities sector and preparation of map mode for economical and ecological exploitation and gradual implementation of projects to improve the energy efficiency of public buildings in Devnya.

Carry out an information campaign among the population regarding the quality of the fuels used and their impact on air quality in the area, as well as energy efficiency in buildings and its impact on fuel consumption. Serious attention is paid to the cleaning of the major roads from accumulated dust and their maintenance in good condition, regular washing of the roads and watering of the green areas, the landscaping initiatives for improving green system balance, etc.

\section{Conclusions}

The results from the long-term study indicate a significant reduction of the concentrations of the pollutants $\mathrm{SO}_{2}, \mathrm{NO}_{2}, \mathrm{CO}, \mathrm{O}_{3}, \mathrm{PM}_{10}, \mathrm{NH}_{3}$ and $\mathrm{C}_{6} \mathrm{H}_{6}$ in the air of Devnya industrial region for the period 20002015. The main reason is related to the implementation of measures for the reduction of pollution set out in IPPC permits for industrial and combustion installations in the area.

After the issuing of IPPC permit No.68/2005 in Agropolihim AD an investment program was introduced which includes the implementation of constant monitoring of hazardous substance emissions, the introduction of suitable purification facilities for waste gases and reconstruction of the ammonia nitrate production installation [34]. The technology is waste-free, highly efficient and with a considerable environmental effect. It meets all the requirements of the European Union for implementation of best practices in the production of nitrogen containing mineral fertilisers. It is equipped with the necessary purification facilities, which guarantee the prevention of emitting in the air of dust and ammonia to below the admissible emission norms, as per the IPPC permit.

For the implementation of the measures in the IPPC permit for Solvay Sodi AD (No. 74/2005), an investment program was started in 2007. The main part of the funds was put into the building of a new line for dense soda ash, a distillation column with low content of emissions and low energy consumption, and other facilities. An important part of the project is the new carbonation column, lime kilns reconstruction, building up the dike of Padina slurry pond, modernization of waste gas treatment facilities: scrubbers and electrostatic filters. All new facilities, as well as the reconstructed facilities the plant already has, fully meet the requirements of the best available techniques and ecological standards [35].

In relation with the requirements of the IPPC permit (No.93/2006г) for Deven Coal Fired Power Plant, a new type steam generator with a circulating boiling layer was introduced in 2010. The new type of boiler is characterised by the fact that the fuel constantly circulates through the furnace and the separators with the aim of increasing the time the particles stay in the furnace, which allows for burning at a lower that usual temperatures. The result is an environmentally friendly installation with very low emissions of dust, nitrogen oxides and sulphur oxides as a result of the adding of lime, with simple construction, reliability, excellent efficiency, freedom and possibilities for burning a large range of solid fuels, which allows for a better use of the initial energy resources [36]. Pursuant to the requirements of the IPPC permit for Devnya Cement AD (No. 63H1/2007, updates No.63-Н1-ИО-А1/2013 and No.63-Н1-ИО-А2/2014) was developed and implemented a new integrated system for management of the environment, quality and energy in conformity with standards ISO 14001, ISO 9001 and ISO 50001, certified by EUROCERT. Documentation has been prepared of all the introduced purification facilities for pollutant emissions in the air (electrostatic filters and sleeve filters) with certain controlled parameters; optimal values of the controlled parameters; monitoring frequency; type and equipment for monitoring the controlled parameters [32]. Instructions for maintaining optimal values of the technological parameters have been developed, guaranteeing optimal operation of the purification facilities. Constant and periodic on-site measuring is performed of hazardous substance emissions in the air from stationary sources of the plant. The implementation of the measures in the IPPC permits for industrial and combustion plants, as well as the measures aimed at the vehicles - light-and heavy-duty and fugitive emission sources, the implementation of strict controls to comply the requirements, contribute greatly for the improvement of air quality in the industrial region and for keeping the established norms for pollutants. 
Long-term Observation of Atmospheric Pollution in an Industrial Region in North-East Bulgaria...

\section{Acknowledgements}

Part of the results in this study were made within a project BG161PO003-1.2.04-0045-C0001/20.08.2013 with the financial support of Operative Programme "Developing the Competitiveness of Bulgarian Economics" 2007-2013, co-financed by the European Union through the European fund of regional development and the national budget of the Republic of Bulgaria

\section{Refernces}

[1] Law on Clean Air, State Gazette /Durzhaven Vestnik/ issue 45/1996, amended State Gazette /Durzhaven Vestnik/ issue 58/2016.

[2] Council Directive 96/61/EC of 24 September 1996 concerning integrated pollution prevention and control, $O B$ L 257/26.

[3] Ordinance /2009 on the Terms and Order for Issuing Permits for IPPC, State Gazette /Durzhaven Vestnik/ issue 80/2009, amended State Gazette /Durzhaven Vestnik/ issue 69/2012.

[4] Environment Protection Law, State Gazette /Durzhaven Vestnik/ issue 91/2002, amended State Gazette /Durzhaven Vestnik/ issue $81 / 2016$.

[5] Directive 2008/1/EC of the European Parliament and of the Council of 15 January 2008 concerning integrated pollution prevention and control, $O B$ L $24 / 8$.

[6] M. A. Cole, R. J. R. Elliot, K. Shimamoto. Industrial Characteristics, Environmental Regulations amd Air Pollution: An Analysis of the UK Manufacturing Sector, Research Paper Series, 2004/22, Leverhulme Centre for Research on Globalisation and Economic Policy, pp 31.

[7] S. C. Doğrupamak, B. Özbay. Investigating Correlation and Variations of Air Pollutant Concentrations under Conditions of Rapid Industrialization-Kocaeli (1987-2009), CLEAN Soil, Air, Water, 39, (7), 2011, 597-604.

[8] J. M.Yoo, M. J. Jeong, D. Kim, W. R. Stockwell et al. Spatiotemporal Variations of Air Pollutants $\left(\mathrm{O}_{3}, \mathrm{NO}_{2}, \mathrm{SO}_{2}, \mathrm{CO}, \mathrm{PM}_{10}\right.$ and VOCs) with Land-use types, Atmospheric Chemistry and Physics, 15, 2015, 10857-10885.

[9] S. Harinath, U. Murthy. Spatial Distribution Mapping for Air Pollution in Industrial Areas- a Case Study, Journal of Industrial Pollution Control, 26, (2), 2010, 217-220.

[10] G. Setimo. Air Quality in Industrial Areas: Studies in the Augusta-Priolo, Gela and Milazzo-Valledel Mela Areas. In: Human Health in Areas with Industrial Contamination, WHO, 2014, Edited by: P. Mudu, B. Terracini, M. Martuzzi.

[11] M. Kharytonov, A. Benselhoub, L. Shupranova, R. Kryvakovska, V. Khlopova. Environmental Assessment of Atmospheric Pollution in Dnipropetrovsk Province (Ukraine), Studia Universitatis "Vasile Goldis", Seria Stiintell Vietii, 25, No (2), 2015, 125130.

[12] S. Dey, S. Gupta, U. Mahanty. Study of Particulate Matter, Heavy Metals and Gaseous Pollutants at Gopalpur (23²9'52.67"N, $\left.87^{\circ} 23^{\prime} 46.08^{\prime \prime}\right)$, a Tropical Industrial Site in Eastern India, IOSR Journal of Environmental Science, Toxicology and Food Technology (IOSR-JESTFT), 8, (2), 2014, 01-13.

[13] P. Padmavati, J. Cherukuri, M. A. Reddy. Ambient Air Pollution Levels in theVicinity of NTTPS Thermal Power Plant, IOSR Journal of Environmental Science, Toxicology and Food Technology (IOSR-JESTFT), 9, (2), 2015, 56-60.

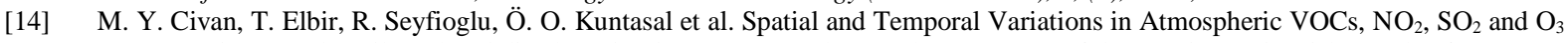
Concentrations at a heavily Industrialized Region in Western Turkey, and Assessment of the Carcinogenic Risk Levels of Benzene, Atmospheric Environment, 103, 2015, 102-113.

[15] J. D. Sarasamma, B. K. Narayanan. Air Quality assessment in the Surroundings of KMML Industrial Area, Chavara in Kerala, South India, Aerosol and Air Quality Research, 14, 2014, 1769-1778.

[16] R. M. S. R. Mohamed, N. M. S. Nizam, A. A. Al-Gheethi, A. Lajis, A. H. M. Kassim. Particulate Matter Levels in Ambient Air Adjacent to Industrial Area, Soft Soil Engineering International Conference (SEIC2015), 2015, IOP Publishing, 1-6.

[17] K. Karar, A. K. Gupta, A. Kumar, A. K. Biswas. Seasonal Variations of PM PM $_{10}$ and TSP in Residential and Industrial Sites in an Urban Area of Kolkota, India, Environmental Monitoring and Assessment, 118, (1-3), 2006, 369-381.

[18] B. Pekey, Ü. Özaslan. Spatial Distribution of $\mathrm{SO}_{2}, \mathrm{NO}_{2}$ and $\mathrm{O}_{3}$ Concentrations in an Industrial City of Turkey using a Passive Sampling Method, CLEAN Soil, Air, Water, 41, (5), 2013, 423-428.

[19] G. K. Artun, N. Polat, O. D. Yay, Ö. O. Üzmez et al. An Integrative Approach for Determination of Air Pollution and its Health Effects in Coal Fired Power Plant Areas by Passive Sampling, Atmospheric Environment, XXX, 2016, 1-15.

[20] S. Arora, A. K. Mahima, R. Pal, A. Singh, A. Tripathi. Air Quality Index and its Possible Impact on Human Health in the Industrial Area of Gajraula, U. P, Journal of Ecophysiology and Occupational Health, 15, (1-2), 2015, 31-37.

[21] O. Ranjan, J. S. Menon, S. M. S. Nagendra. Assessment of Air Quality Impacts on Human Health and Vegetation at an Industrial Area, Journal of Hazardous, Toxic, and Radioactive Waste, 20, (4), 2016.

[22] M. F. Lópes-Cima, J. Garcia-Pérez, B. Pérez-Gomez, N. Araganés, G. Lópes-Abente, A. Tardón, M. Pollán. Lung Cancer Risk and Pollution in an Industrial Region of Nirthern Spain: a hospital-based case-control study, International Journal of Health Geographics, 10, (10), 2011, 01-13.

[23] N. Gull, Y. Nawaz, M. Ali, N. Hussain, R. Nawaz, S. K. Mushtag. Industrial Air Pollution and Effects on Human's respiratory System (A Sociological Study by Broun Shugar Mill District Jhang, Pakistan), Academic Journal of Interdisciplinary Studies, 2, (3), 2013, 535-545, MCSER Publishing, Rome, Italy.

[24] Y. O. Khaniabadi, G. Goundarzi, S. M. Daryanoosh, A. Borgini, A. Tittareli, A. De Marco. Exposure to $\mathrm{PM}_{10}, \mathrm{NO}_{2}$ and $\mathrm{O}_{3}$, and Impacts on Human Health, Environmental Science and Pollution Research, 2016.

[25] C. Poboon, W. Jongjaiphakdee, T. Singkham. Air Pollution Management in Rayong's Induastrial Area, Thailand. In: Air Pollution XX, WIT Transactions on Ecology and the Environment, 157, 2012, 189-199.

[26] M. Kharytonov, N. Gristan, L. Anisimova. Chapter: Environmental Problems Connected with air pollution in the Industrial Regions of Ukraine, In: Global Atmospheric Change and its Impact on Regional Air Quality, NATO Science Series, 16, 2002, $215-222$.

[27] Annual Report on the Condition of the Environment, Regional Inspectorate of Environment and Water Resources, Varna, 20002015 .

[28] Ordinance No12/2010 on the Norms for Sulphur Dioxide, Nitrogen Dioxide and Particulate Matter, Lead, Benzene, Carbon Oxide and Ozone in Ambient air, State Gazette /Durzhaven Vestnik/ issue 58/2010.

[29] Annual Report on the Performance of the Activities for Which an IPPC Permit No.68/2005 was issued to Agropolihim AD, 20062015.

[30] Annual Report on the Performance of the Activities for Which an IPPC Permit No. 74/2005 was issued to Solvay Sodi AD, 20062015.

[31] Annual Report on the Performance of the Activities for Which an IPPC Permit No. 93/2006 was issued to Deven AD, $2007-2015$. 
[32] Annual Report on the Environment and on the Performance of the Activities for Which an IPPC Permit No. 63-H1/2007 was issued to Devnya-Cement AD, (Updates No. 63-H1-ИО-A1/2013 and No. 63-H1-ИО-А2/2014), 2008-2015.

[33] Ordinance No14/1997 on the Norms and Admissible Concentrations of Pollutants in the Ambient air of Populated Areas, State Gazette /Durzhaven Vestnik/ issue 88/1997, amended State Gazette /Durzhaven Vestnik/ issue 14/2004.

[34] R. Chuturkova, S. Radeva, M. Stefanova. Assessment of Harmful Emissions in the Ambient Air from the Production of Nitrogen and Phosphate Fertilizers, Sustainable Development, 18, 2014, 128-133.

[35] S. Radeva, R. Chuturkova, M. Stefanova. Assessment of Measures for Reduction Harmful Emissions in Air from Soda Ash Production Plant in Devnya, Bulgaria, International Journal of Engineering and Advanced Technology, 4 (5), 2015, 139-146.

[36] R. Chuturkova Dynamics of Harmful Emissions from a Coal-Fired Thermal Power Plant in the Industrial Region of Devnya, Bulgaria, International Journal of Engineering Research and Technology, 5, (8), 2016, 59-64.

[37] R. Chuturkova, M. Stefanova. Assessment of NOx emissions from nitric acid production and their effect upon ambient air quality in Devnya region, Journal Scientific and Applied Research, vol.4, 2013, 163-170.

[38] M. Stefanova, R. Chuturkova, E. Sokolovski, N. Ilieva. Dispersion modelling of nitrous oxide emissions from a nitric acid plant in Devnya Region, Bulgaria, International Journal of Research in Engineering and Technology, 3, (5), 2014, 448-457.

[39] M. Todorova Air Pollution with Sulphur Oxides from Industry in SouthWestern and South Eastern Regions of Bulgaria. Journal Scientific and Applied Research, 5, 2014, 213-224.

[40] C. Cafaro, P. Ceci, L. De Giorgi. Effects of IPPC Permits on Ambient Air Quality, International Journal of Environmental and Ecological Engineering, 2, (2), 2015, 96-100.

[41] Directive 2010/75/EU of the European Parliament and of the Council of 24 November 2010 on industrial emissions (integrated pollution prevention and control), $O B$ L334/17.

[42] Programme for Reduction of the Levels of Pollutants in Ambient air and Achieving the Established Norms for Hazardous Substances (Updates), Devnya, 2011 